\title{
$\mathrm{Fe}_{3} \mathrm{O}_{4}$ Nanoparticles as Additives for GAMMA-Ray Shielding: Structural and Surface Characterization
}

\author{
Violeta Nikolić ${ }^{1)}$ \\ Mirjana Milić ${ }^{1)}$ \\ Sonja Jovanović ${ }^{1)}$ \\ Vladimir Girman ${ }^{2)}$
}

\begin{abstract}
Monodisperse samples of magnetite nanoparticles in the size range of 5-13nm, were prepared by solvothermal synthesis and coprecipitation method. Obtained nanoparticles were characterized by different measurement techniques: $X$-ray diffraction analysis, transmission electron microscopy, selected area electron diffraction measurement, and Fourier transform infra-red spectroscopy. Measurements confirmed that the utilized synthesis methods are able to produce size and shape-controlled nanoparticles of a high-quality, that is of the technological importance. The results of the performed study represent the first stage in preparation of the $\mathrm{Fe}_{3} \mathrm{O}_{4}$ nanoparticles as an additive to concrete, which will be used for the construction of the special military facilities where it is necessary to provide a protection against $\gamma$-ray radiation.
\end{abstract}

Key words: nanoparticles, nanomagnetite particles, morphological structure, additives, concrete, gamma ray radiation, radiation protection, facilities protection.

\section{Notations and symbols}

\begin{tabular}{|c|c|}
\hline$A T R$ & - attenuated total reflection \\
\hline$d_{c r}$ & - crystallite diameter \\
\hline FTIR & - Fourier transformation infra-red spectroscopy \\
\hline$h k l$ & - Miller indices of the plane \\
\hline HRTEM & - high resolution transmission electron microscopy \\
\hline$J C P D S$ & - Joint Committee on Powder Diffraction Standards \\
\hline$S A E D$ & - selected area electron diffraction \\
\hline S1 & - sample prepared by solvothermal method \\
\hline$S 2$ & $\begin{array}{l}\text { - sample prepared by coprecipitation method } \\
\text { (nanoparticles obtained from ferrofluid) }\end{array}$ \\
\hline$S 3$ & $\begin{array}{l}\text { - sample prepared by coprecipitation method } \\
\text { (nanoparticles obtained from precipitate) }\end{array}$ \\
\hline TEM & - transmission electron microscopy \\
\hline$\Delta$ & - wavenumber separation value \\
\hline$\lambda$ & - $\mathrm{Cu} \mathrm{K} \alpha$ radiation wavelength \\
\hline$\theta$ & - Bragg angle \\
\hline
\end{tabular}

\section{Introduction}

$\mathrm{O}$ $\mathrm{NE}$ of the most challenging problems during the last century was to face with electromagnetic interference pollution [1-3]. Electromagnetic pollution has been significantly increased during the $20^{\text {th }}$ century, due to the technological progress of the humanity. Prominent problem, which has not yet been solved, is that the electromagnetic interference disturbs functioning of devices, equipment, and systems used for commercial, industrial and military applications $[4,5]$. The type and the amount of shielding needed for electromagnetic radiation protection depends on the penetrability of the radiation [6]. It is important to point out that, compared to the other types of ionizing radiation, gamma radiation is characterized by the highest penetration power [7]. Protection against the gamma radiation should enable the reduction of the environmental electromagnetic background and suppress the appearance of secondary waves.

Due to the electrical neutrality of gamma rays, the interaction between gamma radiation and matter represents a statistical phenomenon. Efficiency of the gamma radiation shielding depends on the energy of the gamma ray, as well as on the nature of the absorbing material [6]. The absorbent material that could be used for the shielding of the gamma radiation is modified concrete $[8,9]$. Conventional concrete represents a material whose properties are dependent on the constituents of the mixture. Since nanomaterials exhibit advanced properties compared to the bulk materials, nanoparticles are often used to improve the properties of the compact materials [10-14]. The effectiveness of concrete as a gamma radiation shield is significantly improved by the addition of the magnetic nanoparticles additives [15-17], since concrete belongs to the group of dielectrics [18]. Reinforced with $\mathrm{Fe}_{3} \mathrm{O}_{4}$ nanoparticles, concrete was found to be a suitable material for the suppression of gamma radiation [4]. Usage of $\mathrm{Fe}_{3} \mathrm{O}_{4}$ nanoparticles as an additive for $\gamma$-ray shielding requires the preparation of the sizelimited $\mathrm{Fe}_{3} \mathrm{O}_{4}$ nanoparticles. Noteworthy, the above mentioned size depends on the energy of gamma radiation. For instance, literature data revealed that suitable size of the magnetite nanoparticles, used as additives for shielding of radiation with frequency $0.7 \mathrm{GHz}$, is $\sim 12 \mathrm{~nm}$ [4].

On the other hand, it is well known that the structural and morphological properties of the nano $\mathrm{Fe}_{3} \mathrm{O}_{4}$ determine its application. At the same time, the particles properties are significantly different depending on the chosen preparation method. Application of the nanoparticles as the additives for

\footnotetext{
1) University of Belgrade, Vinča Institute of Nuclear Sciences, Mike Petrovića Alasa 12-14, P.O. Box 522, 11001 Belgrade, SERBIA

2) Pavol Jozef Šaf́rik University, Institute of Physics, Department of Condensed Matter Physics, Park Angelinum 9 , 04154 Košice, SLOVAKIA

Correspondence to: Violeta Nikolić; e-mail: violeta@vin.bg.ac.rs
} 
radiation shielding implies the preparation of the samples characterized by uniformity in the particles size and shape.

In this study, two different synthesis routes were employed to prepare an appropriate candidate, containing $\mathrm{Fe}_{3} \mathrm{O}_{4}$ nanoparticles additive, for the gamma radiation shielding: solvothermal synthesis and coprecipitation method. Expected size of the particles prepared by solvothermal synthesis is under $10 \mathrm{~nm}$, and does not fulfill the size criteria necessary for the above mentioned application. For that reason, this synthesis method was performed in order to prepare nanoparticle seeds, whose size will be increased via seedmediated solvothermal growth. On the other hand, coprecipitation method enables synthesis of the particles that fulfill size limitation required for the preparation of the additive for gamma radiation shielding. Comparative study of the structural and surface properties of the samples obtained in three different ways was performed, in order to determine compatibility of the prepared nanoparticles for use as the additives for protection against $\gamma$-ray irradiation of the special military facilities used by an army (underground command and telecommunication centers, special storage facilities of war material, water tanks, etc.).

X-ray diffraction (XRD) measurements were done by a Rigaku RINT-TTRIII using $C u K \alpha(\lambda=1.5418 \mathrm{~A})$. Diffraction patterns were recorded in the $2 \theta$ range: $10-70^{\circ}$, with a scanning rate $0.02 \%$ min. Qualx Program was used for data analysis. Fourier transformation infra-red (FTIR) spectroscopy was performed by Nicolet IS 50 FTIR Spectrometer, in the mid infrared region. Sampling technique used to collect spectra was attenuated total reflectance (ATR). Data were analyzed by the Program Omnic. Transmission electron microscopy (TEM) was done by collecting micrographs at Jeol JEM 2100 transmission electron microscope operating at $200 \mathrm{kV}$. Images were processed in the Program ImageJ.

\section{Experimental results and discussion Synthesis of the samples Solvothermal synthesis of the sample $S 1$}

Sample S1 was prepared by the solvothermal method. $\mathrm{Fe}\left(\mathrm{SO}_{4}\right) \cdot 7 \mathrm{H}_{2} \mathrm{O}$ was used as a precursor of the iron ions [19]. Solution of the sodium hydroxide, water, ethanol and oleic acid was prepared in molar proportion 1:2.2:0.8:0.2. Precursors were magnetically mixed for 30 minutes at the room temperature; afterwards, another solution, obtained by dissolving $0.56 \mathrm{~g}$ of the $\mathrm{Fe}\left(\mathrm{SO}_{4}\right) \cdot 7 \mathrm{H}_{2} \mathrm{O}$ in $14 \mathrm{ml}$ of $\mathrm{H}_{2} \mathrm{O}$ was added in the stirring mixture, and stirred for 15 minutes. Then, the solution was shifted to teflon autoclave, where it was kept at $180^{\circ} \mathrm{C}$ for $10 \mathrm{~h}$. Cooled solution was washed with ethanol and n-hexane (in the volume proportion $1 / 3: 2 / 3$ ), at least three times. Washed precipitate consisted of $\mathrm{Fe}_{3} \mathrm{O}_{4} / \mathrm{OA}$ nanoparticles, and it was dried at $80^{\circ} \mathrm{C}$ for $2 \mathrm{~h}$.

\section{Coprecipitation synthesis of the samples S2 and S3}

Sample $\mathrm{S} 2$ was obtained by the coprecipitation method, using $\mathrm{FeCl}_{2} \cdot 4 \mathrm{H}_{2} \mathrm{O}$ and $\mathrm{FeCl}_{3} \cdot 6 \mathrm{H}_{2} \mathrm{O}$ salts as precursors of the iron ions [20]. $5.4 \mathrm{~g} \mathrm{FeCl}_{2} \cdot 4 \mathrm{H}_{2} \mathrm{O}$ and $13.52 \mathrm{~g} \mathrm{FeCl}_{3} \cdot 6 \mathrm{H}_{2} \mathrm{O}$ were separately dissolved in $10 \mathrm{ml} \mathrm{H}_{2} \mathrm{O}$, in the UV bath. After homogenization of the mixtures, solution of the $\mathrm{Fe}^{2+}$ ions had been added to the solution of the $\mathrm{Fe}^{3+}$ ions. In another beaker $20 \mathrm{ml} \mathrm{H} \mathrm{H}_{2} \mathrm{O}$ was added. Under the magnetic stirring, the drop of the homogenized solution of the iron salts was added into the $20 \mathrm{ml} \mathrm{H}_{2} \mathrm{O}$. Then, a drop of the ammonia was put into the stirring solution, to start the nucleation process. Afterwards, the mixture of the iron salts was added into the stirring glass at once. To the obtained solution, $17 \mathrm{ml}$ ammonia was added dropwise. $150 \mathrm{ml} \mathrm{H}_{2} \mathrm{O}$ was added to the prepared mixture, and the solution was stirred further for 30 minutes. The solution was placed onto the permanent magnet, to separate coprecipitate. Washing of the coprecipitate was performed with distilled water, at least three times. After the third washing, ph of the solution was 9.5. To decrease ph, $1 \mathrm{M} \mathrm{HCl}$ was added until the solution ph reached the value 5.7, and then the solution was dialyzed against $0.001 \mathrm{M} \mathrm{HCl}$ solution. After the dialysis process had been finished $(p h=3)$, the solution was again placed onto the permanent magnet, until the precipitate was separated. Certain amount of the prepared ferrofluid was dried at $60^{\circ} \mathrm{C}$ for $48 \mathrm{~h}$, and the obtained powder was labeled as sample S2, while the coprecipitate was dried under the equal conditions, and labeled as a sample S3.

In the Table 1. labels of the samples and synthesis methods used in this study are shortly presented.

Table 1. Samples labels and performed preparation method.

\begin{tabular}{|c|c|}
\hline \hline Sample & Preparation method \\
\hline \hline S1 & Nanoparticles obtained by solvothermal synthesis \\
\hline S2 & Coprecipitation [nanoparticles from ferrofluid] \\
\hline S3 & Coprecipitation [nanoparticles from coprecipitate] \\
\hline
\end{tabular}

\section{Structural analysis}

Structural analysis of the samples was performed by the Xray diffraction and TEM measurements.
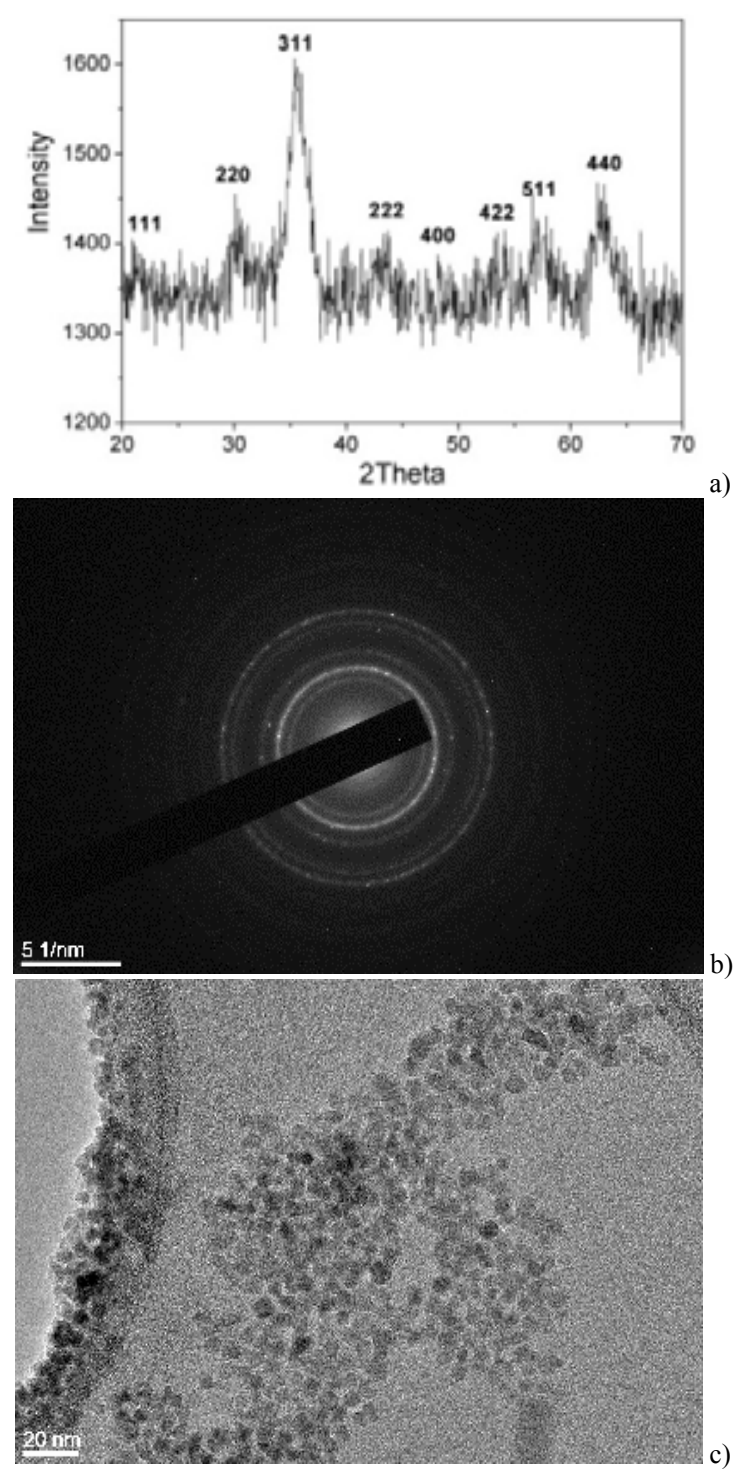


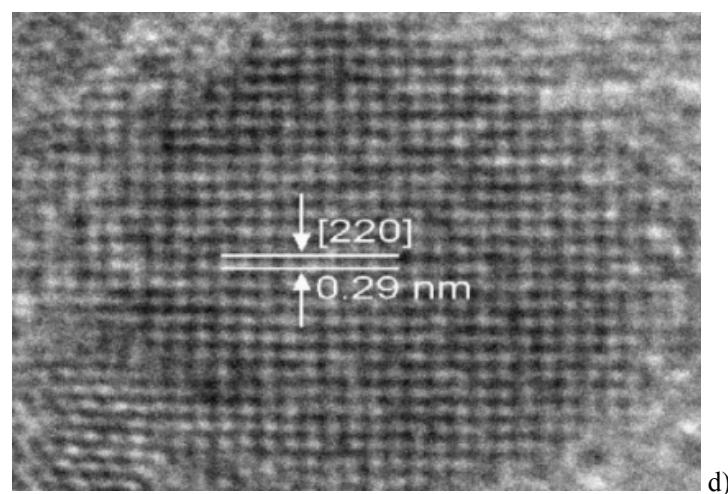

Figure 1. Images of the sample S1: a) XRD pattern; b) SAED pattern; c) TEM image; d) HRTEM.

Fig.1.a) presents diffraction pattern of the sample S1. Position of the diffraction maxima confirmed that the examined samples possess cubic spinel structure (JCPDS Qualx card: 00-900-2674, space group: Fd3m). From the position of the most pronounced diffraction maximum at $2 \Theta=35^{\circ}$, average crystallite size was determined by using the Scherrer's formula, and assuming that the nanoparticles are spherical in shape. Estimated crystallite size of the particles S1 was $5 \mathrm{~nm}$. Since both magnetite and maghemite are characterized by the spinel structure (inverse and normal, respectively), $\mathrm{X}$ ray diffraction technique is not suitable to confirm the presence neither of the magnetite nor of the maghemite nanoparticles in the investigated sample.

Figures 1b)-d) show results of the TEM measurements. SAED measurement confirmed the formation of the magnetite phase, while the transmission electron micrographs were used to analyze the particles size and shape. According to the observed SAED diffraction rings (Fig.1b)), determined inter plane distances could be attributed to the $\mathrm{Fe}_{3} \mathrm{O}_{4}$ phase (Table 2).

Table 2. Estimated inter plane distances of the sample S1

\begin{tabular}{|c|c|c|}
\hline $\begin{array}{c}\text { Estimated inter plane } \\
\text { distances [nm] }\end{array}$ & $\begin{array}{c}\text { Theoretical values of the in- } \\
\text { ter plane distances (JCPDS: } \\
00-900-2674)[n m]\end{array}$ & $\begin{array}{c}h k l \text { indices of the } \\
\text { corresponding plane }\end{array}$ \\
\hline \hline 0.29283 & 0.29648 & 220 \\
\hline 0.25452 & 0.25284 & 311 \\
\hline 0.2111 & 0.20965 & 400 \\
\hline 0.17476 & 0.14824 & 422 \\
\hline 0.16162 & 0.16138 & 511 \\
\hline 0.15005 & 0.14824 & 440 \\
\hline
\end{tabular}

Diffraction rings in the SAED pattern are well pronounced and consistent with the X-ray diffraction pattern (Fig.1a)), demonstrating a high crystallinity of the particles. TEM micrographs of the sample S1 are shown in Fig.1c) and d). Images confirmed that particles are monodisperse and spherical in shape. The determined mean value of the particles size is $5 \mathrm{~nm}$ (Fig.1c)), which is in a very good agreement with the crystallite size value extracted from the XRD measurement. The observed agreement points out to the single-crystal nature of the particles. HRTEM micrograph (Fig.1d)) enables observation of the lattice fringes, confirming high crystallinity of the sample. The determined interplane distance for 220 plane $(0.29 \mathrm{~nm})$ is in accordance with the SAED analysis.

Fig. 2 shows the structural analysis of the sample S2. Cubic spinel structure of the sample S2 is observed at Fig.2a) (JCPDS Qualx card: 00-900-2674). The pronounced narrowing of diffraction maxima points to the bigger mean crystallite sizes $\left(d_{c r}=13 \mathrm{~nm}\right.$, according to $\left.2 \theta=35^{\circ}\right)$ of the particles. Fig.2b) presents the SAED pattern of the sample S2, depicting to the magnetite presence (Table 3).
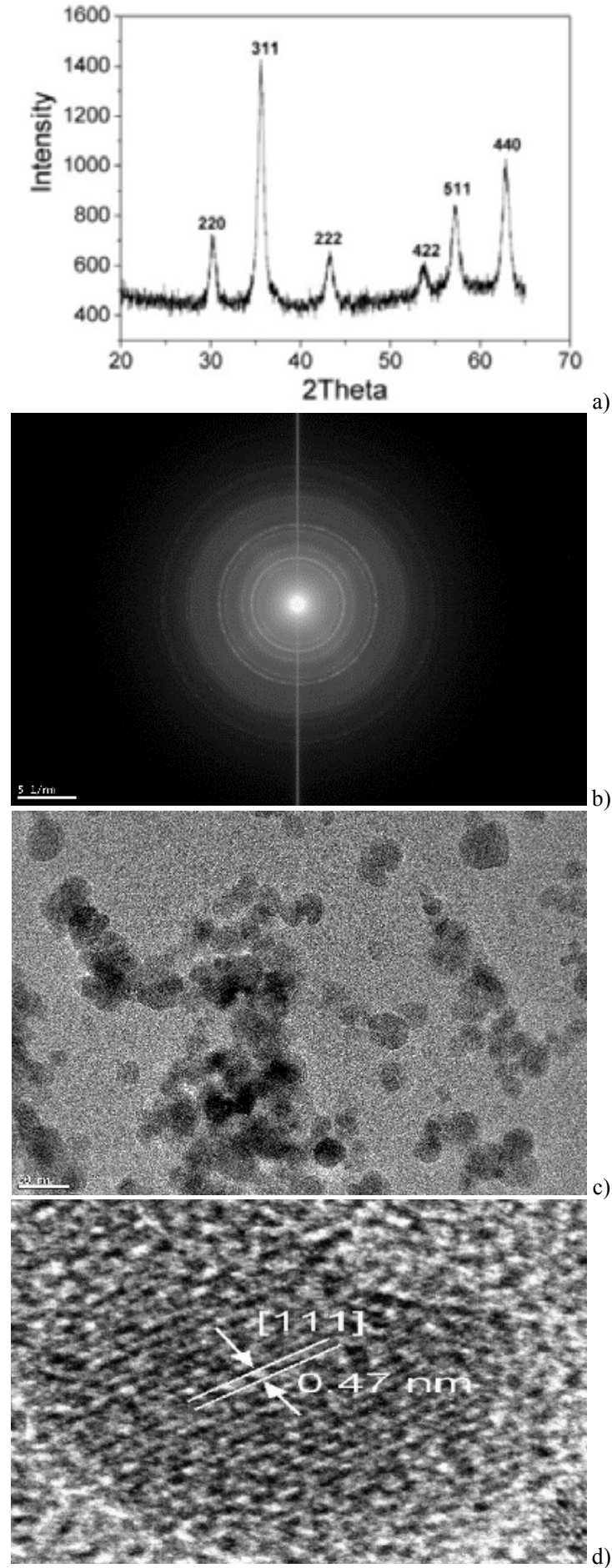

Figure 2. Images of the sample S2: a) XRD pattern; b) SAED pattern; c) TEM image; d) HRTEM image

Table 3. Estimated interplane distances of the sample S2

\begin{tabular}{||c|c|c||}
\hline $\begin{array}{c}\text { Estimated inter- } \\
\text { plane distances [nm] }\end{array}$ & $\begin{array}{c}\text { Theoretical values of the in- } \\
\text { ter plane distances (JCPDS: } \\
\text { 00-900-2674) [nm] }\end{array}$ & $\begin{array}{c}\text { hkl indices of the } \\
\text { corresponding } \\
\text { plane }\end{array}$ \\
\hline \hline 0.29855 & 0.29648 & 220 \\
\hline 0.25439 & 0.25284 & 311 \\
\hline 0.21193 & 0.20965 & 400 \\
\hline 0.15004 & 0.14824 & 440 \\
\hline 0.16243 & 0.16138 & 511 \\
\hline
\end{tabular}

Micrograph (Fig.2c)) shows rather uniform particle sizes (determined average size is $12 \mathrm{~nm}$ ) of almost spherical nanoparticles. Fig.2d) presents HRTEM image, depicting to the nearly spherical shape of the nanoparticles. Clearly 
observed lattice fringes pointed to the high crystallinity of the sample. Estimated interplane distance for 111 plane $(0.47 \mathrm{~nm})$ is in agreement with the theoretical value $(0.48415 \mathrm{~nm})$ and confirms the presence of the magnetite nanoparticles.

Fig. 3 presents theresults of the structural investigation of the sample $\mathrm{S} 3$.
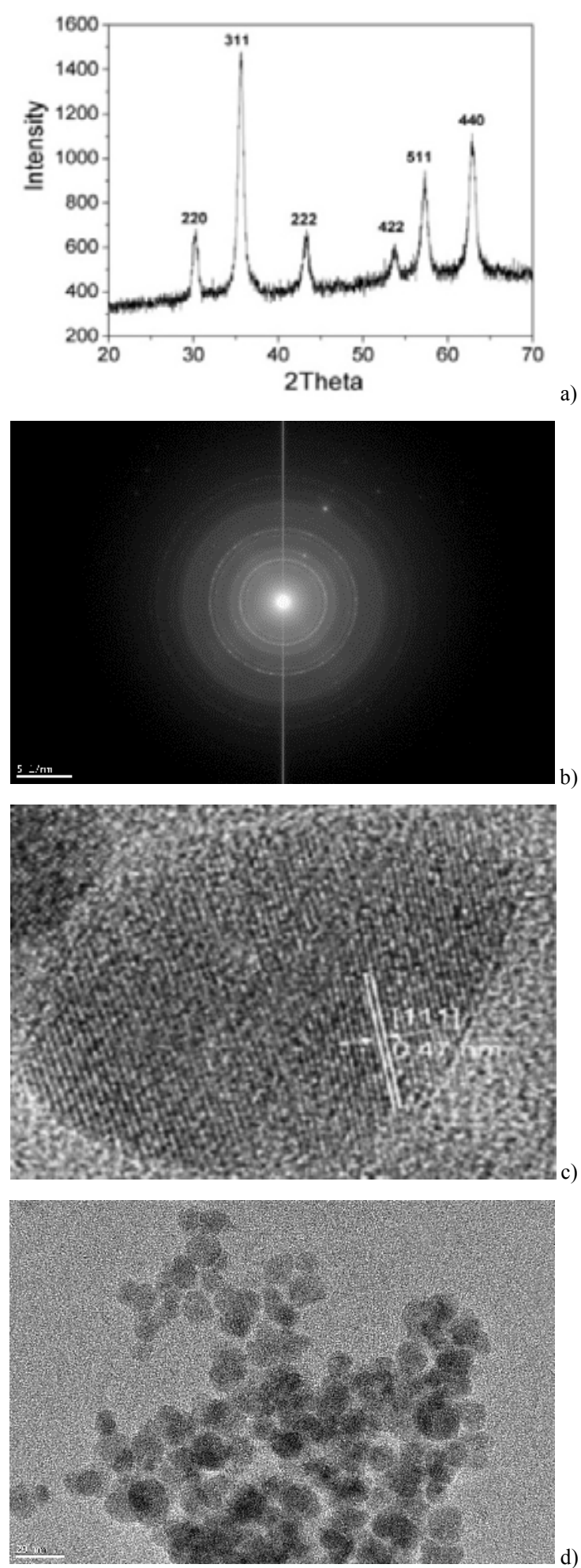

Figure 3. Images of the sample S3: a) XRD pattern; b) SAED pattern; c) TEM image; d) HRTEM

Sample 3 exhibited very similar diffraction pattern as the sample S2 (Fig.3a)). Mean crystallite size was estimated according to the position of the most pronounced diffraction maximum, $d_{c r}=13 \mathrm{~nm}$. Fig. $3 \mathrm{~b}$ ) shows SAED, that is confirming magnetite presence. Most pronounced interplane distances and corresponding planes are presented in Table 4.
Table 4. Estimated interplane distances of the sample S3

\begin{tabular}{|c|c|c||}
\hline $\begin{array}{c}\text { Estimated inter plane } \\
\text { distances [nm] }\end{array}$ & $\begin{array}{c}\text { Theoretical values of the inter } \\
\text { plane distances (JCPDS: 00- } \\
\text { 900-2674) [nm] }\end{array}$ & $\begin{array}{c}h k l \text { indices of the cor- } \\
\text { responding plane }\end{array}$ \\
\hline \hline 0.26031 & 0.25284 & 311 \\
\hline 0.21439 & 0.20965 & 400 \\
\hline 0.17559 & 0.17117 & 422 \\
\hline 0.15299 & 0.14824 & 440 \\
\hline 0.16633 & 0.16138 & 511 \\
\hline
\end{tabular}

TEM image (Fig.3c)) shows that the particles shape is nearly spherical: round and oval. Estimated mean particle size is $11 \mathrm{~nm}$. HRTEM image enable more detailed observation of the particle shape; the particle is round, particularly more elongated (ellipticity is increased, compared to the samples S1 and S2). Sample S3 is also characterized by a high cristallinity, that is confirmed by the presence of the welldefined lattice fringes. The determined interplane distance, $0.47 \mathrm{~nm}$, corresponds to the 111 plane of the magnetite, and represent an additional confirmation that the sample contains $\mathrm{Fe}_{3} \mathrm{O}_{4}$ nanoparticles.

TEM micrographs presented in Figures 2c) and 3c) displayed similar particles size, shape, as well as the similar degree of the particles agglomeration in the investigated samples. Nevertheless, the fact that the nanoparticles of the sample S3 precipitated at $p h=3$, while at the same time nanoparticles of the sample S2 remained in the solution forming a ferrofluid, points to the higher degree of agglomeration and wider particle size distribution of the sample S3. On the other hand, the preparation of the sample $\mathrm{S} 2$ for TEM measurements required drying of the ferrofluid, followed by dissolving of the obtained powder in the appropriate solvent. Since the coprecipitation synthesis did not involve the presence of the surfactant agent, as a result of these processes, the obtained sample expressed a higher degree of agglomeration compared to the ferrofluid nanoparticles, and more similar properties to the sample S3. It is important to point out that ferrofluid nanoparticles of the sample S2 are characterized by higher monodispersity and lower degree of agglomeration. The above properties of the S2 nanoparticles enable the formation of the ferrofluid, while the bigger, agglomerated nanoparticles, precipitate. On the contrary, due to the presence of the capping agent (oleic acid) the sample S1 retains a high monodispersity, regardless of the treatment performed to prepare the sample for the TEM measurement.

Structural analysis confirmed that all investigated samples are characterized by an inverse spinel structure, corresponding to the magnetite phase. According to the TEM results, a high crystallinity of the particles is observed. Particles possess mostly spherical morphology. Although all samples showed high monodispersity, the most pronounced monodispersity is observed for the sample S1, due to the presence of surfactant layer around each nanoparticle.

\section{Surface analysis}

FTIR spectroscopy was used to identify bonds attached to the particles surface, as well as to verify the presence of the magnetite or maghemite phase, since this technique is sensitive to the cation or vacancy order in the crystal. Figures 4a)-c) present FTIR spectra of the investigated samples.

Fig.4a) presents FTIR spectrum of the sample S1. Broad band centered around $3300 \mathrm{~cm}^{-1}$ appeared as a result of the stretching of the hydroxide groups. Residue of the ethanol used during the washing procedure is observed through the appearance of the $1119 \mathrm{~cm}^{-1}$ and $997 \mathrm{~cm}^{-1}$ vibrations [21], attributed to the $\mathrm{C}-\mathrm{O}$ stretching from ethanol and $\mathrm{O}-\mathrm{H}$ out-ofplane bond, respectively. Further, observed broad bands in the 
high-wavenumber region confirmed presence of the oleic acid capping of the magnetite nanoparticles. Bands at $2954 \mathrm{~cm}^{-1}$ and $2918 \mathrm{~cm}^{-1}$ originate from the symmetric $\mathrm{CH}_{2}$ and asymmetric $\mathrm{CH}_{2}$ vibrations of the oleic acid. Two broad bands, centered at 1523 and $1406 \mathrm{~cm}^{-1}$, are linked to the asymmetric and symmetric C-O vibrations of the oleic acid [22, 23], pointing to the presence of the adsorbed oleic acid molecule onto the $\mathrm{Fe}_{3} \mathrm{O}_{4}$ active sites $[24,25]$. Bidentate bridging value is determined based on the wavenumber separation value. Separation value in the wavenumber range: $\Delta=110-200 \mathrm{~cm}^{-1}$ is characteristic for bidentate bridging [24]. Estimated value, $\Delta=113 \mathrm{~cm}^{-1}$, points to the chemisorbed oleic acid onto the $\mathrm{Fe}_{3} \mathrm{O}_{4}$ sites $[24,25]$. In other words, $\mathrm{COO}^{-}$group is covalently bonded to the Fe surface atoms.

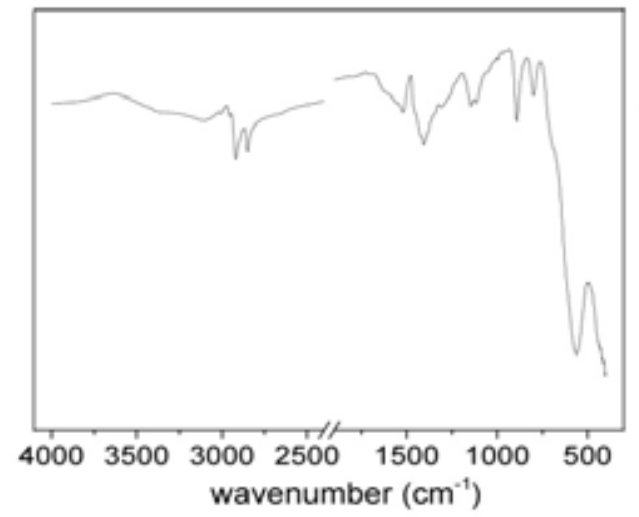

$\mathrm{T} \%$
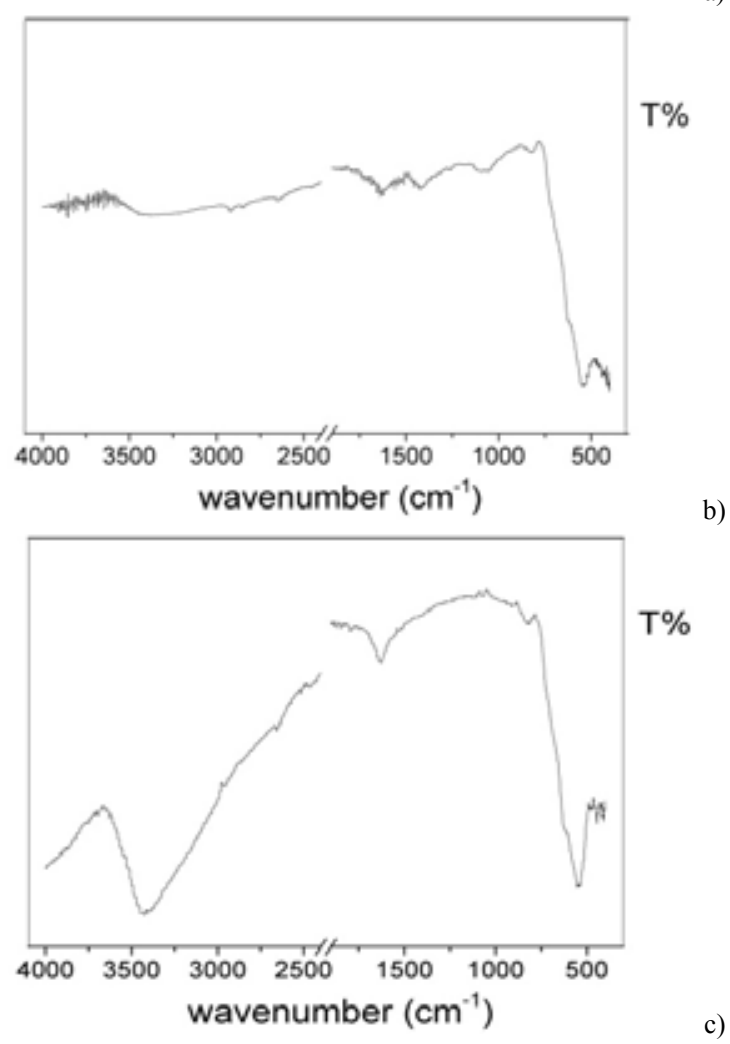

Figure 4. FTIR spectra of the investigated sample: a) S1; b) S2; c) S3

In the low-wavenumber region, which is a fingerprint area for the iron oxide vibrations, two bands observed at positions: 406 and $545 \mathrm{~cm}^{-1}$, are attributed to the $\mathrm{Fe}-\mathrm{O}$ vibrations, characteristic for stretching vibrations of metal ion at the tetrahedral A-site of the inverse spinel structure [26, 27]. The absence of the shoulder at $621 \mathrm{~cm}^{-1}$, characteristic for maghemite [28], confirms the presence of the magnetite phase. According to the Fig.4a), the sample S1 contained $\mathrm{Fe}_{3} \mathrm{O}_{4}$ nanoparticles, which is in accordance with the Fig.1.
Fig.4a) also confirmed the presence of the capping agent-oleic acid. Oleic acid was used in the synthesis procedure to ensure the sample monodispersity, and to prevent oxidation of the particles and stoichiometry alteration that brings to the formation of the $\gamma-\mathrm{Fe}_{2} \mathrm{O}_{3}$ phase.

FTIR spectra of the samples S2and S3 are presented at Figures $4 b)$ and c), respectively. High wavenumber region displays the presence of intermolecularly bonded $\mathrm{O}-\mathrm{H}$ groups in the samples ( $3300 \mathrm{~cm}^{-1}$ band). Also, the samples are characterized with the band at $1626 \mathrm{~cm}^{-1}$, that is attributed to the $\mathrm{H}-\mathrm{O}-\mathrm{H}$ scissoring vibrations of free or adsorbed water. The band at $1455 \mathrm{~cm}^{-1}$ is ascribed to the $\mathrm{O}-\mathrm{H}$ in-plane band, while the band at $997 \mathrm{~cm}^{-1}$ is assigned to the $\mathrm{O}-\mathrm{H}$ out-of-plane vibration. Both samples show vibration at $550 \mathrm{~cm}^{-1}$, that confirms the presence of the Fe ion at A-site of the spinel structure. On the other hand, in Fig.4c) the shoulder at $620 \mathrm{~cm}^{-1}$ is observed denoting the presence of the surface maghemite layer in the $\mathrm{S} 3$ sample, which is absent in the sample S2.

The observed presence of maghemite at the $\mathrm{Fe}_{3} \mathrm{O}_{4}$ surface is in accordance with the literature data, which defined magnetite as an oxide whose surface is always passivated by a maghemite layer, since magnetite oxidize immediately during the air exposure. Considering the fact that the samples S2 and S3 contained bare magnetite nanoparticles prepared without surfactant agent, stoichiometry of the magnetite nanoparticles obtained by coprecipitation is preserved by a static repulsion of the particles. The absence of the shoulder at $621 \mathrm{~cm}^{-1}$ in Fig.4a) and b) points to the fact that $\mathrm{Fe}_{3} \mathrm{O}_{4}$ nanoparticles of the samples $\mathrm{S} 1$ and $\mathrm{S} 2$ contain very thin surface layer of $\gamma$ $\mathrm{Fe}_{2} \mathrm{O}_{3}$, which is under the FTIR detectability threshold. According to the Fig.4c), sample S3 possesses ticker layer of the $\gamma-\mathrm{Fe}_{2} \mathrm{O}_{3}$ phase, placed on the $\mathrm{Fe}_{3} \mathrm{O}_{4}$ particles surface.

\section{Conclusion}

Three samples containing magnetite nanoparticles were prepared by two different chemical synthesis routes: solvothermal synthesis (S1) and coprecipitation method (S2 and S3). X-ray diffraction analysis confirms that the samples are characterized by the iron oxide spinel structure, without traces of the other iron oxide phase impurities. The samples prepared by different synthesis routes are characterized by different sizes, although all prepared samples displayed high-crystallinity. Mean particle size of the sample obtained by solvothermal synthesis was $5 \mathrm{~nm}$, while the samples obtained by coprecipitation consisted of the particles bigger in size $\left(d_{S 2}=13 \mathrm{~nm}\right.$ and $d_{S 3}=11$ $\mathrm{nm})$. TEM analysis shows that the particles of the investigated samples are mostly spherical in shape (round and oval). SAED analysis confirmed that the examined samples contained the magnetite nanoparticles. FTIR investigation revealed that the sample $\mathrm{S} 1$ possesses magnetite nanoparticles capped with oleic acid, while the samples S2 and S3 contained bare magnetite nanoparticles. Performed analysis of the samples shows that different synthesis methods resulted in the preparation of the high-quality nanoparticles. The studied samples could be further employed for the preparation of the concrete, reinforced with the synthesized particles, which will be utilized for the protection against gamma ray of the special military facilities used by an army.

\section{Acknowledgements}

This work has been supported by the Ministry of Education, Science and Technological Development of the Republic of Serbia (2011-2017), under the Grants Nos. III 45015, OI171027 and III 45006. 


\section{Literature}

[1] LING,J., ZHAI,W., FENG,W., SHEN,B., ZHANG,J.,ZHENG,W.G.: Facile preparation of lightweight microcellular polyetherimide / graphene composite foams for electromagnetic interference shielding, ACS applied materials \& interfaces, 2013, Vol.5, No.7, pp.2677-2684.

[2] REDL,R.: Electromagnetic environmental impact of power electronics equipment, Proceedings of the IEEE, 2001, Vol.89, No.6, pp.926-938.

[3] CHEN,Y., WANG,Y., ZHANG,H.B., LI,X., GUI,C.X., YU.Z.Z.: Enhanced electromagnetic interference shielding efficiency of polystyrene / graphene composites with magnetic $\mathrm{Fe}_{3} \mathrm{O}_{4}$ nanoparticles, Carbon, 2015, Vol.82, No.3, pp.67-76.

[4] LESBAYEV,A.B., ELOUADI,B., BORBOTKO,T.V., MANAKOV, S.M., SMAGULOVA,G.T., BOIPRAV,O., PRIKHODKO,N.G.: Influence of Magnetite Nanoparticles on Mechanical and Shielding Properties of Concrete, Eurasian Chemico-Technological Journal, 2017, Vol.19, No.3, pp.223-229.

[5] MA,M.T., KANDA,M., CRAWFORD,M.L., LARSEN,E.B.: A review of electromagnetic compatibility/interference measurement methodologies, Proceedings of the IEEE, 1985, Vol.73, No.3, pp.388-411.

[6] https://sciencedemonstrations.fas.harvard.edu/presentations $/ \alpha-\beta-\gamma-$ penetration-and-shielding, downloaded 12.12.2017.

[7] MORRISON,P.: On gamma-ray astronomy, Il Nuovo Cimento (19551965), 1958, Vol.7, No.6, pp.858-865.

[8] KHARITA,M.H., TAKEYEDDIN,M., ALNASSAR,M., YOUSEF,S.: Development of special radiation shielding concretes using natural local materials and evaluation of their shielding characteristics, Progress in Nuclear energy, 2008, Vol.50, No.1, pp.33-36.

[9] AKKURT,I., AKYLDIRIM,H., MAVI,B., KILINCARSLAN,S., BASYGIT,C.: Gamma-ray shielding properties of concrete including barite at different energies, Progress in Nuclear Energy, 2010, Vol.52, No.7, pp.620-623.

[10] NIKOLIĆ,V., TADIĆ,M., SPASOJEVIĆ,V.: Thermal stability and magnetic properties of $\varepsilon-\mathrm{Fe}_{2} \mathrm{O}_{3}$ polymorph, 7th International Scientific Conference on Defensive Technologies, OTEH 2016, 06-07. October, Military Technical Institute, Belgrade, SERBIA, ISBN 978-86-8112382-9, 2016, pp.507-512

[11] NIKOLIĆ,V., TADIĆ,M., $\quad$ PANJAN,M., KOPANJA,L., CVJETIČANIN,N., SPASOJEVIĆ,V.: Influence of annealing treatment on magnetic properties of $\mathrm{Fe}_{2} \mathrm{O}_{3} / \mathrm{SiO}_{2}$ and formation of $\varepsilon-\mathrm{Fe}_{2} \mathrm{O}_{3}$ phase, Ceramics International, 2017, Vol.43, No.3, pp.3147-3155.

[12] FABIAN,M., BOTTKE,P., GIRMAN,V., DUVEL,A., DA SILVA,K.L., WILKENING,M., HAHN,H., HEITJANS,P., SEPELAK,V.: A simple and straightforward mechanochemical synthesis of the far-from-equilibrium zinc aluminate, $\mathrm{ZnAl}_{2} \mathrm{O}_{4}$, and its response to thermal treatment, RSC Advances, 2015, Vol.5, No.2, pp.54321, DOI: 10.1039/c5ra09098a.

[13] MILIĆ,M., MATIĆ,M.V., LAZAROV,N.DJ.: The dependence of critical temperature on oxygen concentration in $\mathrm{YBa}_{2} \mathrm{Cu}_{3} \mathrm{O}_{6+x}$ in terms of the fragmented chain model, Central European Journal of Physics, 2011, Vol.9, No.3, pp.690-697.

[14] RICCI,A., POCCIA,N., CAMPI,G., CONERI,F., BARBA,L., ARRIGHETTI,G., POLENTARUTTI,M., BURGHAMMER,M., SPRUNG,M., ZIMMERMANN,M., BIANCONI,A.: Networks of superconducting nano-puddles in $1 / 8$ doped $\mathrm{YBa}_{2} \mathrm{Cu}_{3} \mathrm{O}_{6.5+y}$ controlled by thermal manipulation, New Journal of Physics, 2014,Vol.16, No.5, pp.1-5,053030, DOI: 10.1088/1367-2630/16/5/053030.
[15] Gencel,O., BROSTOW,W., OZEL,C., FILIZ M.: Concretes containing hematite for use as shielding barriers, Journal of Materials Science, 2010, Vol.16, No.3, pp.249-256.

[16] HORSZCZARUK,E., BRZOZOWSKI,P., SIKORA,P., CENDROWSKI,K., MIJOWSKA,E.: The Effect of Nanomagnetite on the Shielding Properties of Cementitious Composites, Construction Materials and Systems, 2017, Vol.55, No.5,pp.1-5.

[17] SHARIF,F., ARJMAND,M., MOUD,A.A., SUNDARARAJ,U., ROBERTS,E.P.: Segregated Hybrid Poly (Methyl Methacrylate) / Graphene / Magnetite Nanocomposites for Electromagnetic Interference Shielding, ACS Applied Materials \& Interfaces, 2017, Vol.9. No.16, pp.14171-14179.

[18] SOUTSOS,M.N., BUNGEY,J.H., MILlARD,S.G., SHAW,M.R., PATTERSON,A.: Dielectric properties of concrete and their influence on radar testing, NDT \& e International, 2001, Vol.34, No.6, pp.419425.

[19] LI,C., WEI,R., XU,Y., SUN,A., WEI,L.: Synthesis of hexagonal and triangular $\mathrm{Fe}_{3} \mathrm{O}_{4}$ nanosheets via seed-mediated solvothermal growth, Nano Research, 2014, Vol.7, No.4, pp.536-543.

[20] ILLES,E., TOMBACZ,E.: The effect of humic acid adsorption on $\mathrm{pH}$ dependent surface charging and aggregation of magnetite nanoparticles, Journal of Colloid and Interface Science, 2006, Vol.295, No.1, pp.115-123.

[21] BRONSTEIN,L.M., HUANG,X., RETRUM,J., SCHMUCKER,A., PINK,M., STEIN,B.D., DRAGNEA,B.: Influence of iron oleate complex structure on iron oxide nanoparticle formation, Chemistry of Materials, 2007, Vol.19, No.2, pp.3624-3632, doi:10.1021/cm062948j.

[22] SOLER,M.A.G., ALCANTARA,G.B., SOARES,F.Q., VIALI,W.R., SARTORATTO,P.P.C., FERNANDEZ,J.R.L., $\quad$ SILVA,S.W., GARG,V.K., OLIVEIRA,A.C., MORAIS,P.C.: Study of molecular surface coating on the stability of maghemite nanoparticles, Surface Science, 2007, Vol.601, No.3, pp.3921-3925, DOI:10.1016 / j.susc.2007.04.029.

[23] LIN-VIEN,D., COLTHUP,N.B., FATELEY,W.G., GRASSELLI,J.G.: The handbook of infrared and raman characteristic frequencies of organic molecules, San Diego: Academic Press, 1991.

[24] LIMAYE,M.V., SINGH,S.B., DATE,S.K., KOTHARI,D., REDDY,V.R., GUPTA,A., SATHE,V., CHOUDHARY,R.J., KULKARNI,S.K.: High coercivity of oleic acid capped $\mathrm{CoFe}_{2} \mathrm{O}_{4}$ nanoparticles at room temperature, The Journal of Physical Chemistry B, 2009, Vol.113, No.27, pp.9070-9076.

[25] WU,N., FU,L., SU,M., ASLAM,M., WONG,K.C., DRAVID,V.P.: Interaction of fatty acid monolayers with cobalt nanoparticles, Nano letters, 2004, Vol.4, No.2, pp.383-386.

[26] CORNELL,R.M., SCWERTMANN,U.: The iron oxides-structure, properties, reactions, Occurences and Uses, Weinheim: Wiley-VCH, 2003.

[27] ISHII,M., NAKAHIRA,M., YAMANAKA,T.: Infrared absorption spectra and cation distributions in $(\mathrm{Mn}, \mathrm{Fe})_{3} \mathrm{O}_{4}$, Solid State Communications, 1972, Vol.11, No.2, pp.209-212.

[28] CHAMRITSKI,I., BURNS,G.: Infrared-and Raman - Active Phonons of Magnetite, Maghemite, and Hematite: A Computer Simulation and Spectroscopic Study, The Journal of Physical Chemistry B, 2005, Vol.109, No.11, pp.4965-4968.

\title{
$\mathrm{Fe}_{3} \mathrm{O}_{4}$ nanočestice kao aditivi za zaštitu od gama-zračenja: Strukturna i površinska karakterizacija
}

\begin{abstract}
Monodisperzni uzorci nanočestica magnetita, veličine između 5-13 nm, su pripremljeni primenom solvotermalne sinteze i metode koprecipitacije. Karakterizacija sintetisanih nanočestica je izvršena primenom nekoliko mernih tehnika: difrakcija H-zraka, transmisiona elektronska mikroskopija, elektronska difrakcija sa odabrane površine i infra-crvena spektroskopija sa Furijeovom transformacijom. Merenja su potvrdila da se primenom pomenutih metoda sinteze dobijaju nanočestice visokog kvaliteta, što je od velikog tehnološkog značaja. Rezultati ove studije predstavljaju prvu fazu pripreme $\mathrm{Fe}_{3} \mathrm{O}_{4}$ nanočestica kao aditiva cementu pri njegovom korišćenju za izradu objekata specijalne namene gde je neophodno ostvariti zaštitu od $\gamma$-zraka.
\end{abstract}




\title{
$\mathrm{Fe}_{3} \mathrm{O}_{4}$ наночастицы как добавки для гама-радиационной защиты: Структурная и поверхностная характеризация
}

\begin{abstract}
Монодисперсные образцы наночастиц магнетита, синтезированные в диапазоне размеров 5-13 нм, были получены методом сольвотермического синтеза и соосаждения. Характеристика синтезированных наночастиц осуществляется с использованием нескольких методов измерения: дифракции рентгеновских лучей, просвечивающей электронной микроскопии, дифракции электронов с выбранных областей и инфракрасной спектроскопии с преобразованием Фурье. Измерения подтвердили, что выполненные методы синтеза способны производить наночастицы с контролируемым размером и формой высокого качества, что имеет большое технологическое значение. Результаты проведённого исследования представляют собой первый этап подготовки наночастиц Fе3О4 в качестве добавок к цементу, который будет использован для строительства военных объектов специального назначения, где это необходимо для защиты от $\gamma$-излучения.
\end{abstract}

Ключевые слова: наночастицы, наномагнитные частицы, морфологическая структура, добавки, цемент, гаммаизлучение, радиационная защита, защита объектов.

\section{Nano particules $\mathrm{Fe}_{3} \mathrm{O}_{4}$ comme additifs pour la protection contre le rayonnement gamma: Caractérisation structurale et de surface}

Les échantillons mono dispersés de nano particules de magnétite de taille de 5-13mm ont été préparés par l'application de la
synthèse solvothermale et par la méthode de coprécipitation. La caractérisation des nano particules synthétisés a été obtenue par
l'emploi de plusieurs techniques de mesure : diffraction des rayons $X$, microscopie électronique à transmission, diffraction
électronique à partir d'une surface sélectionnée et la spectroscopie infrarouge à transformée de Fourier. Les mesurages ont
confirmé que par l'utilisation des méthodes citées de synthèse on obtenait les nano particules de haute qualité ce qui est très
important de point de vue technologique. Les résultats de cette étude représentent la première phase de la préparation des nano
particules Fe3O4 comme un additif au béton pendant son emploi pour la construction des installations militaires spéciales où il est
indispensable pour la réalisation de protection contre les rayons $Y$.

Mots clés: nano particules, nano particules magnétiques, structure morphologique, additifs, béton, rayonnement gamma, protection contre le rayonnement, protection des installations. 